\title{
PENGARUH KEPERCAYAAN, KEMUDAHAN DAN KUALITAS INFORMASI TERHADAP KEPUTUSAN PEMBELIAN DARING DI APLIKASI BUKALAPAK PADA MAHASISWA POLITEKNIK NEGERI BATAM
}

\author{
Kartika Ayuningtiyas ${ }^{1}$ ) Hendra Gunawan, S.E., M.Sc. ${ }^{2}$ ) \\ 1) Prodi Administrasi Bisnis Terapan Politeknik Negeri Batam, email: kayuningtiyas@gmail.com \\ 2) Prodi Administrasi Bisnis Terapan Politeknik Negeri Batam, email: hendra@ polibatam.ac.id
}

\begin{abstract}
The purpose of this study was to determine and analyze the influence of trust, ease of use and information quality on purchasing decision in Bukalapak application of students at Batam State Polytechnic. The sample in this study are students of Batam State Polytechnic who ever made purchases online in Bukalapak application. The sampling method using purposive sampling. The analysis technique used in this research is multiple regression analysis. The results show that simultaneously, trust, ease of use and information quality are affecting positively and significantly in purchasing decision in Bukalapak application of students at Batam State Polytechnic. Partially, trust is affecting not significantly in purchasing decision in Bukalapak application of students at Batam State Polytechnic. Ease of use and information quality are affecting positively and significantly in purchasing decision in Bukalapak application of students at Batam State Polytechnic.
\end{abstract}

Keywords: Ease of Use, Information Quality, Purchasing Decision, Trust.

\section{abstrak}

Tujuan dari penelitian ini adalah untuk mengetahui dan menganalisis pengaruh kepercayaan, kemudahan dan kualitas informasi terhadap keputusan pembelian daring di aplikasi Bukalapak pada mahasiswa Politeknik Negeri Batam. Sampel dalam penelitian ini adalah mahasiswa Politeknik Negeri Batam yang pernah melakukan pembelian secara daring di aplikasi Bukalapak. Metode pengambilan sampel menggunakan purposive sampling. Teknik analisis yang digunakan dalam penelitian ini adalah analisis regresi berganda. Hasil penelitian menunjukkan bahwa secara simultan, kepercayaan, kemudahan dan kualitas informasi berpengaruh positif dan signifikan terhadap keputusan pembelian daring di aplikasi Bukalapak pada mahasiswa Politeknik Negeri Batam. Secara parsial, variabel kepercayaan berpengaruh tidak signifikan terhadap keputusan pembelian daring di aplikasi Bukalapak pada mahasiswa Politeknik Negeri Batam. Variabel kemudahan dan kualitas informasi berpengaruh positif dan signifikan terhadap keputusan pembelian daring di aplikasi Bukalapak pada mahasiswa Politeknik Negeri Batam.

Kata kunci: Kemudahan, Kepercayaan, Keputusan Pembelian, Kualitas Informasi 


\section{PENDAHULUAN}

\section{Latar Belakang}

Pertumbuhan internet di dunia dari tahun ke tahun semakin meningkat. Internet world stats pada tahun 2017 mencatat sampai saat ini pengguna internet di dunia telah mencapai 3,7 miliar pengguna. Pertumbuhan pengguna internet di seluruh dunia mencapai 566\% sejak tahun 2000-2012, dan Asia merupakan penyumbang terbesar sekitar $44,8 \%$ dari total pengguna internet di seluruh dunia (Barhanudin, 2015). Saat ini, populasi pengguna internet terbesar diduduki oleh Asia dengan jumlah pengguna sekitar 1,8 miliar atau 55\% dari total keseluruhan.

Banyaknya pengguna internet terutama di Indonesia memberikan kesempatan atau peluang yang besar bagi pelaku bisnis untuk menciptakan online shopping. Berdasarkan survei yang dilakukan Asosiasi Penyelenggara Jasa Internet Indonesia (APJII) bahwa $34 \%$ pengguna internet mencari informasi di internet mengenai jasa/produk yang akan dibeli. Hal ini merupakan peluang yang semakin besar bagi pelaku bisnis untuk menjalankan bisnisnya dengan membuat online shopping.

Aktifitas jual beli daring atau yang lebih sering dikenal dengan e-commerce dengan model market place adalah yang paling banyak diminati oleh pengguna internet karena mempunyai kelebihan dengan memberikan keamanan tambahan dalam setiap transaksi. Setiap transaksi, market place tersebut menjadi pihak ketiga bagi pembeli dan penjual dengan menerima pembayaran dan menjaganya hingga produk dikirimkan oleh penjual dan akan meneruskan pembayaran kepada penjual hingga produk tersebut sampai ke pembeli.

Jika dilihat dari survei perilaku pengguna internet Indonesia berdasarkan perangkat yang dipakai, 47,6\% atau 63,1 juta pengguna internet menggunakan perangkat mobile dalam penggunaan internet. Hal ini menyebabkan semakin banyak fitur-fitur yang diciptakan untuk mempermudah aktivitas manusia. Situs-situs belanja daring pun juga membuat dalam bentuk aplikasi agar mudah dijangkau oleh pengguna internet, seperti kaskus, zalora, blanja.com, mataharimall dan masih banyak lagi yang bisa ditemukan.

Begitu juga dengan pemilik Bukalapak yang ikut membuat aplikasi pada mobile setelah situs mereka diminati oleh para pengguna internet. Bukalapak lebih dulu mengembangkan market place dalam bentuk situs lalu menambahkan aplikasi untuk mempermudah pengguna dalam mengaksesnya. E-commerce dengan model bisnis market place yang bermunculan saat ini menawarkan pengalaman belanja daring dengan cepat dan mudah yang menawarkan berbagai produk berdasarkan kategori seperti, pakaian, buku, elektronik, mainan anak, produk kecantikan, peralatan masak, peralatan traveling dan masih banyak lagi kategori yang bisa ditemukan.

Pembelian adalah keputusan konsumen mengenai apa yang dibeli, apakah membeli atau tidak, kapan membeli, di mana membeli dan bagaimana cara pembayarannya (Sumarwan dalam Hardiawan, 2013). Kemudian Sumarwan (2003) mendefiniskan keputusan konsumen sebagai suatu keputusan sebagai pemilikan suatu tindakan dari dua atau lebih pilihan alternatif.

Selanjutnya, keputusan dalam membeli memiliki beberapa faktor yang yang menjadi pertimbangan diantaranya kepercayaan (trust), bertransaksi secara daring memiliki kepastian dan informasi yang tidak simetris. Oleh sebab itu harus ada rasa saling percaya antara penjual dan pembeli (Gefen, 2002), kepercayaan konsumen akan e-commerce merupakan salah satu faktor kunci melakukan kegiatan jual beli secara daring (Koufis dan Hampton-Sosa, 2004), kemudian kemudahan (ease of use) Davis dkk (dalam Hardiawan, 2013) dan Gunawan, H., \& Sari, E. (2016) menyatakan bahwa 
Kartika \& Hendra, pengaruh kepercayaan, kemudahan dan kualitas informasi terhadap keputusan ...

perceived of ease of use sebagai keyakinan akan kemudahan penggunaan, yaitu tingkatan di mana user percaya bahwa teknologi/sistem tersebut dapat digunakan dengan mudah dan bebas dari masalah dan selanjutnya kualitas informasi (information quality), kualitas informasi didefiniskan sebagai persepsi pelanggan terhadap kualitas informasi tentang produk atau layanan yang disediakan oleh sebuah website (Park dan Kim, 2003 dalam Hardiawan, 2013). Semakin berkualitas informasi yang diberikan kepada pembeli daring, maka akan semakin tinggi minat pembeli daring untuk membeli produk tersebut (Park, C.H dkk dalam Hardiawan 2013). Faktor-faktor tersebut yang akan dijadikan variabel independen dari penelitian ini.

\section{Rumusan Masalah}

Berdasarkan latar belakang masalah yang telah diuraikan sebelumnya, maka dapat dirumuskan masalah sebagai berikut :

1. Sejauh mana kepercayaan (trust) berpengaruh terhadap keputusan pembelian daring di aplikasi Bukalapak.

2. Sejauh mana kemudahan (ease of use) berpengaruh terhadap keputusan pembelian daring di aplikasi Bukalapak.

3. Sejauh mana kualitas informasi (information quality) berpengaruh terhadap keputusan pembelian daring di aplikasi Bukalapak.

4. Sejauh mana kepercayaan (trust), kemudahan (ease of use), dan kualitas informasi (information quality) berpengaruh terhadap keputusan pembelian daring di aplikasi Bukalapak.

\section{Tujuan Penelitian}

Sesuai dengan permasalahan yang diajukan dalam penelitian, maka tujuan dari penelitian ini adalah:

1. Untuk mengetahui sejauh mana kepercayaan (trust) berpengaruh terhadap keputusan pembelian daring di aplikasi Bukalapak.
2. Untuk mengetahui sejauh mana kemudahan (ease of use) berpengaruh terhadap keputusan pembelian daring di aplikasi Bukalapak.

3. Untuk mengetahui sejauh mana kualitas informasi (information quality) berpengaruh terhadap keputusan pembelian daring di aplikasi Bukalapak.

4. Untuk mengetahui sejauh mana kepercayaan (trust), kemudahan (ease of use), dan kualitas informasi (information quality) berpengaruh terhadap keputusan pembelian daring di aplikasi Bukalapak.

\section{Manfaat Penelitian}

1. Manfaat Praktis

Hasil penelitian diharapkan dapat memberi kontribusi dan manfaat bagi para pelaku bisnis daring khususnya Bukalapak agar dapat merumuskan strategi pemasaran yang baik supaya Bukalapak semakin maju, unggul dan terus melakukan inovasi agar menjadi aplikasi jual beli daring nomor satu yang dapat dipercaya.

2. Manfaat Teoritis

Penelitian ini diharapkan dapat memperluas pengetahuan serta menambah wawasan peneliti mengenai manajemen perusahaan pada umumnya dan penerapan strategi online shop pada khususnya.

\section{KAJIAN PUSTAKA \\ Kepercayaan (Trust)}

Menurut Rousseau dkk (dalam Armayanti 2011), kepercayaan adalah wilayah psikologis yang merupakan perhatian untuk menerima apa adanya berdasarkan harapan terhadap perilaku yang baik dari orang lain. Kepercayaan konsumen didefinisikan sebagai kesediaan satu pihak untuk menerima risiko dari tindakan pihak lain berdasarkan harapan bahwa pihak lain akan melakukan tindakan penting untuk 
pihak yang mempercayainya, terlepas dari kemampuan untuk mengawasi dan mengendalikan tindakan pihak yang dipercaya (Mayer dkk dalam Armayanti 2011). Menurut $\mathrm{Ba}$ dan Pavlou (dalam Armayanti 2011) mendefinisikan kepercayaan sebagai penilaian hubungan seseorang dengan orang lain yang akan melakukan transaksi tertentu sesuai dengan harapan dalam sebuah lingkungan yang penuh ketidakpastiaan.

Perbedaan antara online trust dengan off-line trust menurut Sung-Joon Yoon (dalam Prabowo 2014) adalah adanya jarak fisik yang nyata antara pembeli dan penjual dengan ketiadaan sales people, serta adanya pemisahan antara pembeli dan produk. Kepercayaan konsumen dalam hal penggunaan data pribadi dan hukum yang akan melindungi mereka menjadi faktor utama yang turut mempengaruhi tingkat kepercayaan mereka terhadap sebuah situs.

\section{Kemudahan (Ease of Use)}

Hal yang menjadi pertimbangan selanjutnya bagi pembeli daring adalah faktor kemudahan penggunaan. Kemudahan Penggunaan didefinisikan sebagai sejauh mana seseorang percaya bahwa menggunakan suatu teknologi akan bebas dari usaha. Nantinya faktor kemudahan ini akan berdampak pada perilaku, yaitu semakin tinggi presepsi seseorang tentang kemudahan menggunakan sistem, semakin tinggi pula tingkat pemanfaatan teknologi informasi (Jogiyanto, 2007).

Menurut Sari (2015) Faktor kemudahan ini terkait dengan bagaimana operasional bertransaksi secara online. Biasanya calon pembeli akan mengalami kesulitan pada saat pertama kali bertransaksi online, dan cenderung mengurungkan niatnya karena faktor keamanan serta tidak tahu cara bertransaksi online. Di lain pihak, ada juga calon pembeli yang berinisiatif untuk mencoba karena telah mendapatkan informasi tentang cara bertransaksi online. Suatu website online shop yang baik adalah yang menyediakan petunjuk cara bertransaksi online, mulai dari cara pembayaran, dan fitur pengisian form pembelian.

\section{Kualitas Informasi (Information Quality)}

Menurut Mukhtar (dalam Luthfiya, 2014) Informasi yang disajikan pada online shop sebaiknya mencakup informasi berkaitan dengan produk dan jasa yang ada pada online shopping. Informasi tersebut sebaiknya berguna dan relevan dalam memprediksi kualitas dan kegunaan produk atau jasa. Untuk memuaskan kebutuhan informasi konsumen/pembeli daring, informasi produk dan jasa harus up-to-date, membantu pembeli daring dalam membuat keputusan, konsisten, dan mudah dipahami.

Hardiawan (2013) menyatakan bahwa di dalam online shopping sebaiknya menyajikan informasi yang mencakup kaitannya dengan produk dan jasa yang ada pada online shopping. Informasi tersebut sebaiknya berguna dan relevan dalam memprediksi kualitas dan kegunaan produk atau jasa. Informasi produk dan jasa harus up-to-date untuk memuaskan kebutuhan konsumen atau pembeli daring. Hal tersebut dapat membantu pembeli di dalam membuat keputusan, konsisten dan mudah dipahami.

\section{Keputusan Pembelian}

Menurut Kotler dan Armstrong (dalam Sari 2015), keputusan pembelian konsumen adalah membeli merek yang paling disukai dari berbagai alternatif yang ada, tetapi dua faktor bisa berada antara niat pembelian dan keputusan pembelian. Faktor pertama adalah sikap orang lain dan faktor yang kedua adalah faktor situasional. Oleh karena itu, preferensi dan niat pembelian tidak selalu menghasilkan pembelian yang aktual.

Secara umum, keputusan adalah pemilihan dari dua atau lebih alternatif pilihan (Schiffman \& Kanuk dalam Hardiawan, 2013). Dengan kata lain untuk membuat keputusan harus terdapat alternatif pilihan. Sebaliknya jika konsumen tidak memiliki alternatif untuk memilih maka 
Kartika \& Hendra, pengaruh kepercayaan, kemudahan dan kualitas informasi terhadap keputusan ...

tidak dapat dikategorikan sebagai pengambilan keputusan.

Berdasarkan uraian di atas dapat disimpulkan bahwa keputusan pembelian merupakan kegiatan pemecahan masalah yang dilakukan individu dalam pemilihan salah satu alternatif yang sesuai dari dua alternatif atau lebih dan dianggap sebagai tindakan yang paling tepat dalam membeli dengan terlebih dahulu melalui tahapan proses pengambilan keputusan.

Proses pengambilan keputusan merupakan perilaku yang harus dilakukan untuk dapat mencapai sasaran, dan dengan demikian dapat memecahkan masalahnya, dengan kata lain proses pemecahan suatu masalah yang diarahkan pada sasaran. Proses keputusan pembelian yang spesifik menurut Kotler dan Armstrong (2008) terdiri dari urutan kejadian berikut: pengenalan kebutuhan, pencarian informasi, evaluasi alternatif, keputusan pembelian dan perilaku pasca pembelian.

\section{METODE PENELITIAN}

\section{Desain/ Jenis Penelitian}

Jenis penelitian pada skripsi ini adalah penelitian eksplanatori (explanatory research), yaitu penelitian yang bermaksud menjelaskan kedudukan variabel-variabel yang diteliti serta hubungan antara satu variabel dengan yang lain (Sugiyono, 2012).

\section{Populasi dan Sampel}

Populasi dalam penelitian ini adalah mahasiswa aktif Politeknik Negeri Batam yang berjumlah 3741 mahasiswa. Pada penelitian ini sampel diambil dengan rancangan purposive sampling. Ukuran sampel ditentukan dengan menggunakan rumus Slovin (Sangadji dan Sopiah dalam Luthfiya 2014) yaitu teknik pengambilan sampel peneliti menggunakan sampel dari populasi dengan rumus:

$$
\mathrm{n}=\frac{\mathrm{N}}{1+N e^{2}}
$$

Keterangan :

$\mathrm{n} \quad=$ Ukuran sampel

$\mathrm{N}=$ Ukuran populasi

e $\quad=$ Taraf Kesalahan

Sehingga jumlah sampel menjadi:

$\mathrm{n}=97,39=100$ responden

$$
\mathrm{n}=\frac{3741}{1+3741(0,1)^{2}}=97,39
$$

Dari hasil perhitungan tersebut maka diketahui besar sampel yang diperlukan adalah 100 responden.

\section{Jenis dan Sumber Data}

Pada penelitian jenis dan sumber data menggunakan data primer.

\section{Teknik Pengumpulan Data}

Teknik pengumpulan data yang digunakan dalam penelitian ini adalah:

\section{Kuesioner}

Kuesioner pada penelitian ini terdiri dari pertanyaan-pertanyaan yang bersumber dari indikator-indikator variabel penelitian. Kuesioner diberikan kepada responden yaitu mahasiswa Politeknik Negeri Batam yang pernah melakukan pembelian daring pada forum jual beli (FJB) di aplikasi Bukalapak.

Pada penelitian ini, penulis menggunakan skala likert. Skala likert digunakan untuk mengukur sikap, pendapat, pengaruh dan persepsi seseorang atau sekelompok orang tentang fenomena sosial (Sugiyono, 2014). Skala likert merupakan skala interval maka bisa dianalisis dengan menggunakan alat analisis parametrik seperti analisis regresi (dalam Suliyanto 2011). Menurut Ghozali (dalam Suliyanto, 2011) juga skala likert dapat dianggap interval. Berikut urutan pengukuran data yang dilakukan: 
Tabel 1 Instrumen Skala Likert Untuk Variabel

\begin{tabular}{lll}
\hline No. & \multicolumn{1}{c}{ Skala Likert } & Skor \\
\hline 1. & Sangat Setuju (SS) & 4 \\
\hline 2. & Setuju (S) & 3 \\
\hline 3. & Tidak Setuju (TS) & 2 \\
\hline 4. & Sangat Tidak Setuju (STS) & 1 \\
\hline
\end{tabular}

(Sumber : Riduwan, 2009)

2. Studi Pustaka

Peneliti mengumpulkan data dengan menggunakan buku-buku literatur yang berhubungan dengan masalah yang diteliti. Metode pengumpulan data melalui buku, jurnal, majalah, situs internet yang berkaitan dengan penelitian yang dilakukan dan menjadi bahan referensi pendukung bagi peneliti.

\section{Validitas dan Reliabilitas}

Untuk mengetahui validitasnya, instrumen disebar kepada responden selanjutnya uji validitas dapat diperoleh dengan menggunakan bantuan program SPSS dan ditentukan validitasnya dengan menggunakan rumus sebagai berikut:

$$
r_{x y}=\frac{N \Sigma x y_{-\left(\sum x\right)}\left(\sum y\right)}{\sqrt{\left(N \Sigma x^{2}-\left(\sum x\right)^{2}\left(N \Sigma y^{2}-(\Sigma y)^{2}\right)\right.}}
$$

\section{Rumus Uji Validitas}

Sumber : Sugiyono, 2012

Keterangan:

Rxy : koefisien korelasi antara $\mathrm{x}$ dan $\mathrm{y}$

$\mathrm{X}$ : jumlah skor dari masing-masing (faktor yang mempengaruhi)

Y : jumlah skor dari seluruh (skor total) $\mathrm{N} \quad$ : banyaknya variabel sampel yang dianalisis

Jika hasil perhitungan ternyata $r_{\text {hitung }}>$ $r$ tabel maka instrumen dianggap valid, sebaliknya jika hasil perhitungan ternyata $r$ hitung $<r$ tabel maka instrumen dianggap tidak valid.
Uji reliabilitas dilakukan dengan tujuan untuk mengetahui konsistensi dari instrumen sebagai alat ukur, sehingga hasil suatu pengukuran dapat dipercaya. Rumus yang digunakan untuk menguji reliabilitas dalam penelitian ini adalah koefisien Alpha Cronbach.

Adapun rumus koefisien reliabilitas Alpha cronbach adalah sebagai berikut:

$$
r_{11}=\left(\frac{n}{n-1}\right)\left(1-\frac{\sum \sigma \mathrm{t} 2}{\sigma \mathrm{t} 2}\right)
$$

Rumus Alpha Cronbach

Sumber: Sugiyono, 2012

Keterangan :

$\mathrm{r}_{11} \quad$ : Reliabilitas yang dicari

n : Jumlah item pertanyaan yang di uji

$\sum \sigma_{\mathrm{t}}{ }^{2} \quad$ : Jumlah varians skor tiap-tiap item

$\sigma_{\mathrm{t}}^{2} \quad$ : Varians total

Menurut Ghozali (2012), bahwa pernyataan yang telah dinyatakan valid dalam uji validitas maka akan ditentukan realibilitasnya dengan kriteria sebagai berikut:

1. Jika nilai Cronbach Alpha > 0,6 maka kuesioner penelitian dinyatakan reliabel (sangat baik/sangat menyakinkan).

2. Jika nilai Cronbach Alpha < 0,6 maka kuesioner penelitian dinyatakan tidak reliabel (kurang menyakinkan).

\section{Teknik Analisis Data}

\section{a. Statistik Deskriptif}

Menurut Sugiyono (2014) statistik deskriptif adalah statistik yang digunakan untuk menganalisis data dengan cara mendeskripsikan atau menggambarkan data yang telah terkumpul sebagaimana adanya tanpa bermaksud membuat kesimpulan yang berlaku untuk umum atau generalisasi. Dalam analisis deskriptif ini akan dikaji bagaimana persepsi yang diberikan oleh responden. Hasil akan ditampilkan dalam bentuk tabel distribusi frekuensi item variabel penelitian yang terdiri dari frekuensi jawaban responden. 
Kartika \& Hendra, pengaruh kepercayaan, kemudahan dan kualitas informasi terhadap keputusan ...

Dasar intrepretasi skor item dalam penelitian dapat digambarkan dalam tabel sebagai berikut:

Tabel 2 Dasar Intrepretasi Skor Item Variabel Penelitian

\begin{tabular}{ccl}
\hline $\mathbf{N}$ & Nilai & \multicolumn{1}{c}{ Intrepretasi } \\
$\mathbf{0}$ & Skor & \\
\hline $\mathbf{1}$ & $0<\mathrm{NS} \leq$ & Berada pada daerah \\
& 1 & sangat negatif \\
\hline $\mathbf{2}$ & $1<\mathrm{NS} \leq$ & Berada pada daerah \\
& 2 & negatif \\
\hline $\mathbf{3}$ & $2<\mathrm{NS} \leq$ & Berada pada daerah \\
& 3 & positif \\
\hline $\mathbf{4}$ & $3<\mathrm{NS} \leq$ & Berada pada daerah \\
& 4 & sangat positif \\
\hline
\end{tabular}

(Sumber: Arikunto, 2010)

\section{b. Statistik Inferensial}

\section{Uji Asumsi Klasik}

Sebelum melakukan analisis regresi berganda, perlu dilakukan pengujian asumsi klasik terlebih dahulu, agar data sampel yang diolah benar - benar dapat mewakili populasi secara keseluruhan. Uji asumsi klasik yang digunakan dalam penelitian ini yaitu uji normalitas, uji multikolinearitas, dan uji heteroskedastisitas.

\section{a. Uji Normalitas}

Uji Normalitas dilakukan untuk mengetahui apakah data terdistribusi dengan normal atau tidak. Uji normalitas dilakukan dengan menggunakan pendekatan kolmogrov smirnov dengan menggunakan tingkat signifikan 5\% maka nilai Asymp.Sig (2-tailed) di atas nilai signifikan 5\% artinya variabel residual berdistribusi normal (Situmorang \& Lufti dalam Luthfiya 2014).

\section{b. Uji Heteroskedastisitas}

Menurut Ghazali (2012) uji heteroskedastisitas dilakukan untuk menguji apakah dalam sebuah model regresi, terjadi ketidaksamaan varians dari residual dari satu pengamatan ke pengamatan lain. Jika varians dari residual dari satu pengamatan ke pengamatan yang lain tetap, maka disebut Homokedastisitas. Jika variansnya berbeda maka disebut Heterokedastisitas.

Menurut Ghazali (2012), model regresi yang baik adalah tidak terjadi heterokedastisitas. Jika ada pola tertentu, seperti titik-titik yang membentuk suatu pola tertentu yang teratur (bergelombang, melebar, kemudian menyempit) maka telah terjadi heteroskedastisitas. Jika tidak ada pola yang jelas serta titik-titik menyebar di atas dan di bawah angka nol pada sumbu Y, maka tidak terjadi heterokedastisitas.

\section{c. Uji Multikolinearitas}

Uji multikolinearitas bertujuan untuk mengetahui adanya hubungan linier yang sempurna diantara variabel-variabel bebas dalam model regresi. Untuk mengetahui ada atau tidaknya gejala multikolinearitas dapat dilihat dari besarnya Tolerance Value dan Variance Inflation Faktor (VIF) melalui program SPSS. Kriteria yang dipakai adalah apabila nilai Tolerence > 0,1 atau nilai VIF < 5 , maka tidak terjadi multikolinearitas di mana:

a. Tolerance value $<0,1$ atau VIF $>10=$ terjadi multikolinearitas

b. Tolerance value $>0,1$ atau $\mathrm{VIF}<10=$ tidak terjadi multikolinearitas

\section{Analisis Regresi Linear Berganda}

Analisis regresi berganda digunakan untuk mengetahui seberapa besar pengaruh variabel bebas (X) yang terdiri dari kepercayaan $\left(\mathrm{X}_{1}\right)$, kemudahan $\left(\mathrm{X}_{2}\right)$ dan kualitas informasi $\left(\mathrm{X}_{3}\right)$ terhadap variabel terikat $(\mathrm{Y})$ yaitu keputusan pembelian.

Persamaan regresi berganda yang digunakan adalah:

$$
Y=a+b_{1} X_{1}+b_{2} X_{2}+b_{3} X_{3}+e
$$


Keterangan:

$\mathrm{Y} \quad=$ variabel keputusan pembelian

a $\quad=$ konstanta

b1...b3 = koefisien regresi

$\mathrm{X}_{1} \quad$ = variabel kepercayaan (trust)

$\mathrm{X}_{2} \quad$ = variabel kemudahan (ease of use)

$\mathrm{X}_{3}$ =variabel kualitas informasi (information quality)

e $\quad=$ standar eror

\section{Uji Hipotesis}

\section{Pengujian Hipotesis Parsial (Uji T)}

Uji t yaitu suatu uji untuk mengetahui signifikansi pengaruh variabel independen dengan parsial atau individual terhadap variabel dependen. Kriteria yang digunakan adalah:

1. $\mathrm{H}_{0}: \mathrm{b} 1=0$, Artinya secara parsial tidak terdapat pengaruh yang positif dan signifikan dari variabel bebas $\left(\mathrm{X}_{1}, \mathrm{X}_{2}\right.$, $\mathrm{X}_{3}$,) yaitu berupa kepercayaan (trust), kemudahan (ease of use) dan kualitas informasi (information quality) terhadap keputusan pembelian (Y).

2. $\mathrm{H} 1: \mathrm{b} 1>0$, Artinya secara parsial terdapat pengaruh yang positif dan signifikan dari variabel bebas $\left(\mathrm{X}_{1}, \mathrm{X}_{2}\right.$, $\mathrm{X}_{3}$,) yaitu berupa kepercayaan (trust), kemudahan (ease of use), kualitas informasi (information quality) terhadap keputusan pembelian (Y).

Sedangkan kriteria pengujian adalah sebagai berikut:

1. Taraf signifikan $(\alpha=0,05)$

2. Distribusi t dengan derajat kebebasan (n $-\mathrm{k})$

3. Apabila $\mathrm{t}$ hitung $>\mathrm{t}$ tabel, maka $\mathrm{H}_{0}$ ditolak dan $\mathrm{H}_{1}$ diterima

4. Apabila $\mathrm{t}_{\text {hitung }}<\mathrm{t}$ tabel, maka $\mathrm{H}_{0}$ diterima dan $\mathrm{H}_{1}$ ditolak

\section{Pengujian Hipotesis Simultan (Uji F)}

Uji $F$ yaitu uji untuk mengetahui pengaruh variabel independen, yaitu kepercayaan (X1), kemudahan (X2), dan kualitas informasi (X3) secara simultan terhadap variabel dependen yaitu keputusan pembelian (Y). Kriteria yang digunakan adalah:
1. $\mathrm{H} 0: \mathrm{b} 1, \mathrm{~b} 2, \mathrm{~b} 3=0$, artinya secara bersama-sama tidak terdapat pengaruh yang positif dan signifikan dari variabel bebas $\left(\mathrm{X}_{1}, \mathrm{X}_{2}, \mathrm{X}_{3},\right)$ yaitu berupa kepercayaan (trust), kemudahan (eay of use), dan kualitas informasi (information quality) terhadap keputusan pembelian (Y).

2. H1 : b1, b2, b3 > 0, artinya secara bersama-sama terdapat pengaruh yang positif dan signifikan dari variabel bebas $\left(\mathrm{X}_{1}, \mathrm{X}_{2}, \mathrm{X}_{3}\right.$, ) yaitu berupa kepercayaan (trust), kemudahan (eay of use) dan kualitas informasi (information quality) terhadap keputusan pembelian (Y).

Sedangkan kriteria pengujiannya adalah sebagai berikut:

1. Taraf signifikansi $(\alpha=0,05)$

2. Distribusi t dengan derajat kebebasan (n $-\mathrm{k})$

3. Apabila $\mathrm{F}$ hitung $>\mathrm{F}$ tabel, maka $\mathrm{H}_{0}$ ditolak dan $\mathrm{H}_{1}$ diterima

4. Apabila $\mathrm{F}$ hitung $<\mathrm{F}$ tabel, maka $\mathrm{H}_{0}$ diterima dan $\mathrm{H}_{1}$ ditolak

\section{Koefisiensi Determinasi (Adj. $\left.\mathbf{R}^{2}\right)$}

Koefisien determinasi $\left(\mathrm{R}^{2}\right)$ pada intinya mengukur seberapa besar kemampuan model dalam menerangkan variabel terikat. Jika $\mathrm{R}^{2}$ semakin besar (mendekati satu), maka dapat dikatakan bahwa pengaruh variabel bebas $\left(\mathrm{X}_{1}, \mathrm{X}_{2}, \mathrm{X}_{3}\right.$, adalah besar terhadap variabel terikat $(\mathrm{Y})$. Hal ini berarti model yang digunakan semakin kuat untuk menerangkan pengaruh variabel bebas yang diteliti terhadap variabel terikat. Sebaliknya jika $\mathrm{R}^{2}$ semakin mengecil (mendekati nol) maka dapat dikatakan bahwa pengaruh variabel bebas $\left(\mathrm{X}_{1}, \mathrm{X}_{2}, \mathrm{X}_{3}\right.$, terhadap variabel terikat $\left(\mathrm{Y}_{1}, \mathrm{Y}_{2}\right)$ semakin kecil. Hal ini berarti model yang digunakan tidak kuat untuk menerangkan pengaruh pada variabel bebas yang diteliti terhadap variabel terikat. 
Kartika \& Hendra, pengaruh kepercayaan, kemudahan dan kualitas informasi terhadap keputusan ...

One-Sample Kolmogorov-Smirnov Test

Unstandardized

\begin{tabular}{llr} 
& & \multicolumn{2}{c}{ Residual } \\
\hline \multirow{2}{*}{ Normal } & \multicolumn{1}{c}{ Mean } & 100 \\
\cline { 2 - 3 } Parameters ${ }^{a, b}$ & $\begin{array}{l}\text { Std. } \\
\text { Deviation }\end{array}$ & $0 \mathrm{E}-7$ \\
\hline & Absolute &, 40517274 \\
\cline { 2 - 3 } Most Extreme & Positive &, 099 \\
\cline { 2 - 3 } Differences & Negative &,- 113 \\
\hline Kolmogorov-Smirnov Z & 1,132 \\
\hline Asymp. Sig. (2-tailed) &, 154 \\
\hline a. Test distribution is Normal. & \\
\hline b. Calculated from data. & \\
\hline
\end{tabular}

\section{HASIL DAN PEMBAHASAN Uji Normalitas}

Uji normalitas dilakukan dengan menggunakan pendekatan histogram, uji scatter plot dan uji statistik kolmogrovsmirnow.

\section{Gambar 1 Histogram Uji Asumsi Klasik}

\section{Gambar 2 Uji Normalitas P- P Plot}

\section{Tabel 3 Hasil Uji Normalitas}

Berdasarkan Gambar 1 Uji normalitas data dengan pendekatan histogram di atas menunjukkan bahwa model regresi yang digunakan telah berdistribusi normal, hal ini dapat dilihat dari garis histogram yang menceng ke kiri atau ke kanan, sehingga penyebaran datanya telah berdistribusi normal.

Berdasarkan Gambar 2 merupakan grafik plot normalitas. Terlihat dari grafik plot normalitas tersebut menunjukkan bahwa titik-titik data menyebar di sekitar garis diagonal yang mengarah ke kanan atas serta penyebarannya mengikuti arah garis diagonal dengan demikian data tersebut bisa dikatakan mempunyai sebaran yang normal.
Berdasarkan Tabel 3 terlihat bahwa Asymp. Sig. (2-tailed) adalah 0,154 dan lebih besar dari alpha $5 \%(0,05)$ ini menunjukkan bahwa variabel residual berdistribusi normal.

\section{Uji Heteroskedastisitas}

Dari diagram scatterplot di bawah terlihat titik-titik menyebar secara acak baik di atas maupun di bawah angka 0 dan sumbu Y, hal ini dapat disimpulkan bahwa tidak terjadi heteroskedastisitas pada model regresi, sehingga model regresi layak untuk digunakan dalam melakukan pengujian.
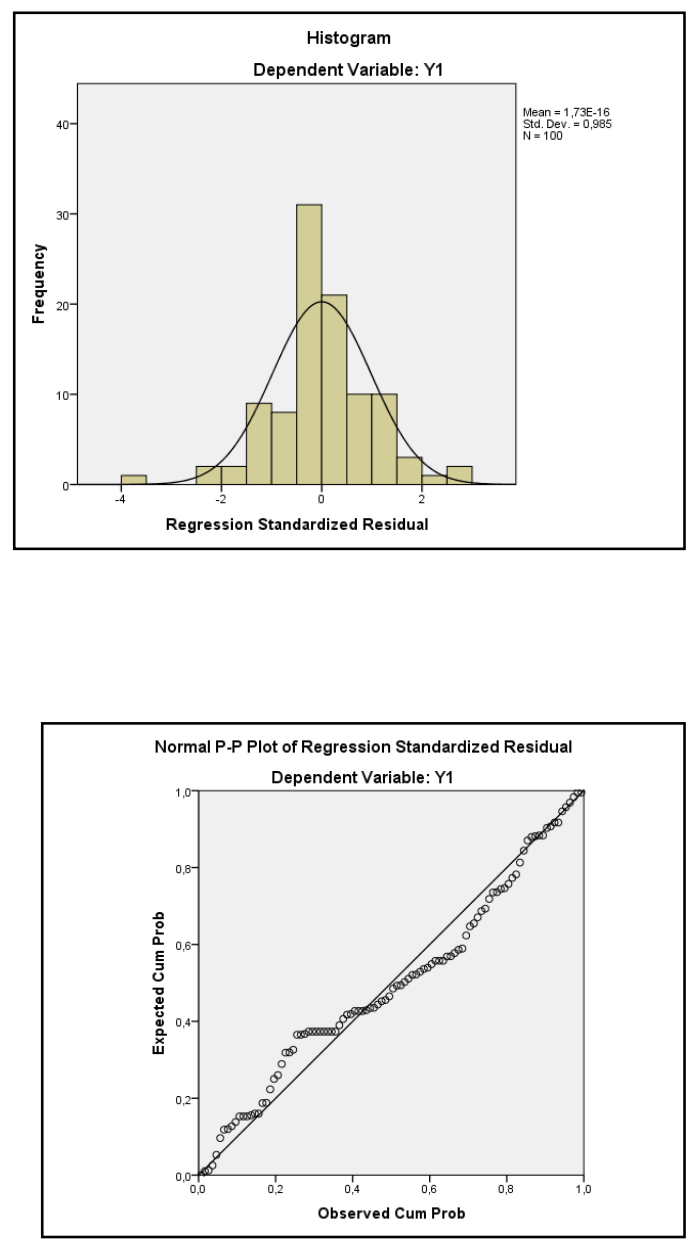


\section{Gambar 3 Grafik Scatter Plot Uji Heteroskedastisitas}

\section{Uji Multikolinearitas}

\section{Tabel 4 Hasil Uji Multikolinearitas}

\begin{tabular}{llcl}
\hline No. & \multicolumn{1}{c}{ Variabel } & $\begin{array}{c}\text { Toler } \\
\text { ance }\end{array}$ & VIF \\
\hline 1. & Kepercayaan $(\mathrm{X} 1)$ & 0,635 & 1,575 \\
\hline 2. & Kemudahan $(\mathrm{X} 2)$ & 0,532 & 1,880 \\
\cline { 2 - 4 } 3. & $\begin{array}{l}\text { Kualitas } \\
\text { Informasi (X3) }\end{array}$ & 0,601 & 1,663 \\
\hline
\end{tabular}

Dari Tabel 4 di atas dapat dilihat bahwa tidak terdapat multikolonieritas dalam model regresi yang digunakan untuk menguji hipotesis, karena variabel independen, yaitu Kepercayaan (X1) mempunyai nilai tolerance yang nilainya lebih besar dari 0,1 yaitu 0,635 dan nilai VIF yang kurang dari 10 yaitu 1,575. Sedangkan variabel Kemudahan (X2) mempunyai nilai tolerance yang nilainya lebih besar dari 0,1 yaitu 0,532 dan nilai VIF yang kurang dari 10 yaitu 1,880 dan variabel Kualitas Informasi (X3) mempunyai nilai tolerance yang nilainya lebih besar dari 0,1 yaitu 0,601 dan nilai VIF yang kurang dari 10 yaitu 1,663. Dengan demikian dapat disimpulkan bahwa model persamaan regresi tidak terdapat problem multikolineritas.

\section{Analisis Regresi Berganda}

Adapun bentuk model persamaan regresi yang dapat dituliskan dari tabel di atas dalam persamaan regresi sebagai berikut:

Beberapa hal yang dapat diketahui dari persamaan tersebut adalah sebagai berikut:

a. Variabel kepercayaan (X1), kemudahan (X2), kualitas informasi (X3) dapat disimpulkan bahwa menunjukkan nilai signifikansi $0,000<0,5$, sehingga dapat disimpulkan bahwa secara bersamasama (simultan) mempunyai pengaruh yang signifikan terhadap keputusan pembelian. Nilai variabel keputusan pembelian memiliki nilai sebesar 5,442.

b. Koefisien regresi $X_{1}$ sebesar $-0,031$ menunjukkan bahwa variabel kepercayaan meningkat $1 \%$ maka variabel keputusan pembelian (Y) akan meningkat sebesar $-0,031$ dengan

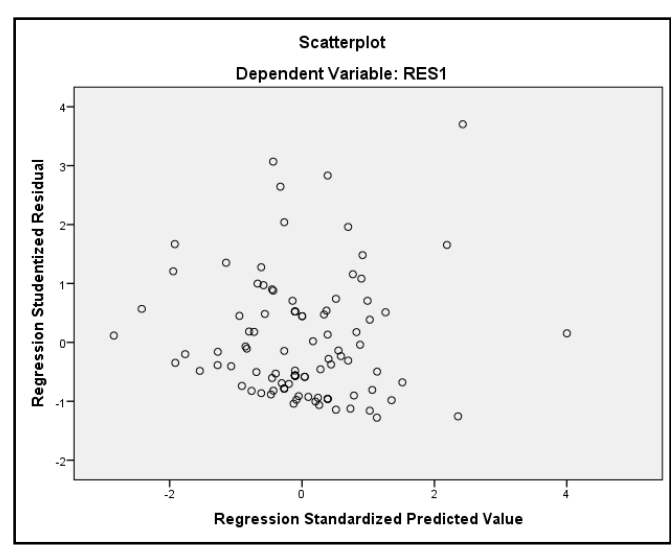

anggapan variabel independen lainnya tetap.

c. Koefisien regresi $X_{2}$ sebesar 0,229 menunjukkan bahwa variabel kemudahan meningkat $1 \%$ maka variabel keputusan pembelian (Y) akan meningkat sebesar 0,229 dengan anggapan variabel independen lainnya tetap.

d. Koefisien regresi $\mathrm{X}_{4}$ sebesar 0,470 menunjukkan bahwa variabel kualitas informasi meningkat $1 \%$ maka variabel keputusan pembelian (Y) akan meningkat sebesar 0,470 dengan anggapan variabel independen lainnya tetap.

\section{Pengujian Hipotesis \\ Hasil Uji Parsial (t)}

Tabel 5 Hasil Uji Parsial

\begin{tabular}{|c|c|c|c|c|c|}
\hline \multicolumn{6}{|c|}{$Y=5,442-0,031 X_{1}+0,229 X_{2}+0,470 X_{3}$} \\
\hline \multicolumn{6}{|c|}{ Coefficients $^{a}$} \\
\hline \multirow[t]{2}{*}{ Model } & $\begin{array}{l}\text { Unsta } \\
\text { d Coe }\end{array}$ & $\begin{array}{l}\text { rdize } \\
\text { ients }\end{array}$ & $\begin{array}{l}\text { Stan } \\
\text { dardi }\end{array}$ & $\mathrm{t}$ & $\begin{array}{l}\mathrm{Si} \\
\mathrm{g} .\end{array}$ \\
\hline & $\mathrm{B}$ & $\begin{array}{l}\text { Std. } \\
\text { Error }\end{array}$ & Beta & & \\
\hline $\begin{array}{ll}\text { (Const } \\
\text { ant) }\end{array}$ & 5,442 & $\begin{array}{r}1,28 \\
6\end{array}$ & & $\begin{array}{r}4,2 \\
33\end{array}$ & $\begin{array}{r}, 00 \\
0\end{array}$ \\
\hline $\begin{array}{l}\text { Keper } \\
\text { cayaa } \\
n\end{array}$ &,- 031 & ,083 &,- 036 & $\begin{array}{r}- \\
, 36 \\
8\end{array}$ & $\begin{array}{r}771 \\
4\end{array}$ \\
\hline $\begin{array}{l}\text { Kemu } \\
\text { dahan }\end{array}$ & ,229 & ,097 & ,248 & $\begin{array}{r}2,3 \\
45\end{array}$ & $\begin{array}{r}, 02 \\
1\end{array}$ \\
\hline
\end{tabular}


Kartika \& Hendra, pengaruh kepercayaan, kemudahan dan kualitas informasi terhadap keputusan ...

\begin{tabular}{llllrr}
\hline Kualit &, 470 &, 095 &, 494 & 4,9 &, 00 \\
as & & & & 64 & 0 \\
Inform & & & & & \\
asi & & & & & \\
\hline
\end{tabular}

. Dependent Variable: Keputusan Pembelian

Dari hasil uji t (parsial) di atas dapat disimpulkan sebagai berikut:

1. $\mathbf{H}_{1}$ : Kepercayaan $\left(\mathrm{X}_{1}\right)$ berpengaruh positif dan signifikan terhadap keputusan pembelian daring di aplikasi Bukalapak.

Hipotesis ini didukung apabila nilai probabilitas signifikansi menunjukkan nilai < 0,05. Berdasarkan Tabel 5 dapat dilihat bahwa variabel kepercayaan diperoleh $t_{\text {hitung }}$ sebesar $-0,368$ dengan signifikansi sebesar 0,714 (sig. < 0,05). Hasil penelitian tersebut menunjukkan angka signifikansi lebih besar dari 0,05 dan $t_{\text {hitung }}$ sebesar $-0,368<t_{\text {tabel }}$ sebesar 1,984, maka model regresi tidak dapat digunakan untuk meprediksi variabel dependen atau dengan kata lain variabel kepercayaan berpengaruh tidak signifikan terhadap variabel keputusan pembelian. Berdasarkan analisis tersebut maka dapat disimpulkan H1 yang diajukan dalam penelitian ini ditolak.

2. $\mathbf{H}_{2}$ : Kemudahan $\left(\mathrm{X}_{2}\right)$ berpengaruh positif dan signifikan terhadap keputusan pembelian daring (Y) di aplikasi Bukalapak.

Hipotesis ini didukung apabila nilai probabilitas signifikansi menunjukkan nilai < 0,05. Berdasarkan Tabel 5 dapat dilihat bahwa variabel kemudahan diperoleh $t_{\text {hitung }}$ sebesar 2,345 dengan signifikansi sebesar 0,021 (sig. < 0,05). Hasil penelitian tersebut menunjukkan angka signifikansi jauh lebih kecil dari 0,05 dan $t_{\text {hitung }}$ sebesar 2,345 $>t_{\text {tabel }}$ sebesar 1,984, maka model regresi dapat digunakan untuk meprediksi variabel dependen atau dengan kata lain variabel kemudahan berpengaruh secara positif dan signifikan terhadap variabel keputusan pembelian. Berdasarkan analisis tersebut maka dapat disimpulkan $\mathbf{H}_{2}$ yang diajukan dalam penelitian ini diterima.
3. H3: Kualitas Informasi $\left(\mathrm{X}_{3}\right)$ berpengaruh positif dan signifikan terhadap keputusan pembelian (Y) daring di aplikasi Bukalapak.

Hipotesis ini didukung apabila nilai probabilitas signifikansi menunjukkan nilai < 0,05. Berdasarkan Tabel 4.15 dapat dilihat bahwa variabel kualitas informasi diperoleh $\mathrm{t}_{\text {hitung }}$ sebesar 4,964 dengan signifikansi sebesar 0,000 (sig. < 0,05). Hasil penelitian tersebut menunjukkan angka signifikansi lebih kecil dari 0,05 dan thitung 4,964 $>\mathrm{t}_{\text {tabel }}$ sebesar 1,984, maka model regresi dapat digunakan untuk meprediksi variabel dependen atau dengan kata lain variabel kualitas informasi berpengaruh secara positif dan signifikan terhadap variabel keputusan pembelian. Berdasarkan analisis tersebut maka dapat disimpulkan $\mathbf{H 3}$ yang diajukan dalam penelitian ini diterima.

\section{Hasil Uji Simultan (F)}

\section{Tabel 6 Hasil Uji Simultan}

\begin{tabular}{lccccr} 
Model & $\begin{array}{c}\text { Sum } \\
\text { of } \\
\text { Squ }\end{array}$ & $\begin{array}{c}\text { D } \\
\text { ares }\end{array}$ & $\begin{array}{c}\text { Mea } \\
\text { Squ }\end{array}$ & F & Sig. \\
& are & & \\
\hline 1 Regr & 146, & 3 & 48,7 & 23 &, 000 \\
essio & 283 & & 61 &, 9 & b \\
$\mathrm{n}$ & & & & 47 & \\
\hline Resid & 195, & 9 & 2,03 & & \\
ual & 477 & 6 & 6 & & \\
\hline Total & 341, & 9 & & & \\
& 760 & 9 & & &
\end{tabular}

a. Dependent Variable: Keputusan Pembelian

b. Predictors: (Constant), Kualitas Informasi,

Kepercayaan, Kemudahan

Dari hasil uji F (simultan) di atas dapat disimpulkan sebagai berikut:

H4: Kepercayaan $\left(\mathrm{X}_{1}\right)$, kemudahan $\left(\mathrm{X}_{2}\right)$ dan kualitas Informasi $\left(\mathrm{X}_{3}\right)$ berpengaruh 
positif dan signifikan terhadap keputusan pembelian (Y) daring di aplikasi Bukalapak.

Hipotesis ini didukung apabila nilai probabilitas signifikansi menunjukkan nilai < 0,05 dan tidak didukung bila sebaliknya. Berdasarkn Tabel 4.16 dapat dilihat bahwa Fhitung sebesar 23,947 dengan probabilitas 0,000 . Hasil penelitian tersebut menunjukkan probabilitas jauh lebih kecil dari 0,05 maka dapat dikatakan bahwa kepercayaan, kemudahan dan kualitas informasi secara bersama-sama berpengaruh positif dan signifikan terhadap keputusan pembelian. Dari F-test didapat Fhitung sebesar 23,947 dan $F_{\text {tabel }}$ dicari pada $\alpha=5 \%$ dengan derajat kebebasan (df) n-k atau 100-4= 96 adalah sebesar 2,466 dengan demikian nilai $\mathrm{F}_{\text {hitung }}=$ $23,947>\mathrm{F}_{\text {tabel }}=2,466$ dan nilai signifikansi sebesar 0,000 (sig. <0,05). Berdasarkan hasil analisis tersebut, maka $\mathbf{H}_{\mathbf{4}}$ yang diajukan dalam penelitian ini diterima.

Koefisien Determinasi

Tabel 7 Hasil Uji Koefisien Determinasi

\begin{tabular}{cc}
\hline $\begin{array}{c}\text { Koefisien Korelasi } \\
(\mathbf{R})\end{array}$ & $\begin{array}{c}\text { Koefisien } \\
\text { Determinasi }\left(\mathbf{R}^{\mathbf{2}}\right)\end{array}$ \\
\hline 0,654 & 0,428 \\
\hline
\end{tabular}

Berdasarkan Tabel 7 dapat diketahui bahwa nilai determinasi $\left(\mathrm{R}^{2}\right)$ adalah 0,428 . Untuk mengetahui besarnya persentase hubungan kepercayaan, kemudahan dan kualitas informasi maka perhitungannya adalah $0,428 \times 100 \%=42,8 \%$. Jadi persentase untuk koefisien determinasi $\left(\mathrm{R}^{2}\right)$ adalah $42,8 \%$, sedangkan untuk $57,2 \%$ dipengaruhi oleh variabel-variabel lain yang tidak dibahas dalam penelitian ini.

\section{SIMPULAN DAN SARAN Simpulan}

Berdasarkan hasil analisis yang dilakukan, maka dapat disimpulkan bahwa secara parsial (uji-t) variabel kepercayaan (trust) berpengaruh tidak signifikan terhadap keputusan pembelian daring di aplikasi Bukalapak pada mahasiswa Politeknik Negeri Batam, variabel kemudahan (ease of use) dan kualitas informasi (information quality) berpengaruh positif dan signifikan terhadap keputusan pembelian daring di aplikasi Bukalapak pada mahasiswa Politeknik Negeri Batam.

Hasil pengujian secara simultan (uji F) menunjukkan bahwa variabel kepercayaan (trust), kemudahan (ease of use) dan kualitas informasi (information quality) secara bersama-sama berpengaruh positif dan signifikan terhadap keputusan pembelian daring di aplikasi Bukalapak pada mahasiswa Politeknik Negeri Batam.

Koefisien Determinan (R2) sebesar 0.428 , yang berarti bahwa variabel keputusan pembelian daring dapat dijelaskan oleh variabel kepercayaan, kemudahan dan kualitas informasi sebesar $42,8 \%$, sedangkan sisanya sebesar $57,2 \%$ dapat dijelaskan oleh variabel-variabel lain diluar model.

\section{Saran}

Bagi penyedia layanan aplikasi Bukalapak diharapkan lebih meningkatkan kepercayaan mengenai produk atau jasa yang ditawarkan kepada responden, misalnya melalui penjelasan lengkap mengenai proses pembelian barang secara daring dimulai dari proses pemesanan, proses pembayaran dan pengiriman barang.

Selanjutnya, diharapkan lebih berinovasi dalam memberikan kemudahan bagi pelanggan serta menciptakan keunggulan-keunggulan baru yang tidak disediakan oleh aplikasi belanja daring lainnya, seperti kemudahan dalam proses pemesanan, pembayaran, pengiriman barang dan pengembalian barang (jika terjadi).

Serta diharapkan memperbaharui informasi yang up to date (terkini), akurat dan lengkap. Kualitas informasi dalam proses pembelian barang diyakini mampu meningkatkan keputusan pembelian secara daring.

Bagi peneliti lanjutan diharapkan hasil penelitian ini dapat dijadikan referensi untuk penelitian yang sejenis serta diharapkan peneliti selanjutnya menambah atau meneliti variabel lainnya yang kemungkinan 
Kartika \& Hendra, pengaruh kepercayaan, kemudahan dan kualitas informasi terhadap keputusan ...

berpengaruh terhadap keputusan pembelian secara daring.

\section{DAFTAR PUSTAKA}

(2017, Desember 14). Diambil kembali dari https://www.bukalapak.com/.

(2017, August). Diambil kembali dari http://www.internetworldstats.com/st ats3.htm .

Adityo, B. (2011). Analisis Pengaruh Kepercayaan, Kemudahan dan Kualitas Informasi Terhadap Keputusan Pembelian Secara On Line di Situs Kaskus. Skripsi pada Fakultas Ekonomi Universitas Diponegoro.

Amilia, R. (2015). Pengaruh Lingkungan Kerja dan Motivasi Terhadap Produktivitas Kerja Karyawan. Skripsi pada Fakultas Ilmu Sosial dan Ilmu Politik Universitas Lampung.

Arikunto, S. (2010). Prosedur Penelitian Suatu Pendekatan Pendekatan Praktik. Jakarta: PT Rineka Cipta.

Arista, E. D., \& Astuti, S. R. (2011). Analisis Pengaruh Iklan, Kepercayaan Merek, dan Citra Merek terhadap Minat Beli Konsumen. widyamanggala.ac.id.

Armayanti, N. (2011). Gambaran Kepercayaan Konsumen Terhadap Pembelian Melalui Media Internet. Skripsi pada Fakultas Psikologi Universitas Sumatera Utara.

Ghafiki, R., \& Setyorini, R. (2017). Pengaruh Kualitas Website Terhadap Keputusan Pembelian Pada Situs BUKALAPAK.COM. openlibrary.telkomuniversity.ac.id.
Ghozali, I. (2012). Aplikasi Analisis Multivariate dengan Program IBM SPSS 20. Semarang: Badan Penerbit Universitas Diponegoro.

Gunawan, H., \& Sari, E. (2016). Penyusunan Sistem Akuntansi Aliston Buana Wisata Batam. JOURNAL OF APPLIED ACCOUNTING AND TAXATION, 1(1), 37-43. https://doi.org/10.5281/zenodo.1302 960

Hadiawan, A. C. (2013). Pengaruh Kepercayaan, Kemudahan, dan Kualitas Informasi Terhadap Keputusan Pembelian Secara Online. Skripsi pada Fakultas Ekonomika dan Bisnis Universitas Diponogero .

Harlan, D. M. (2014). Pengaruh Kemudahan, Kepercayaan dan Risiko Persepsian Terhadap Minat Bertransaksi Menggunakan E-Banking Pada UMKM di Yogyakarta. E-print Universitas Negeri Yogyakarta.

Harman Malau, P. (2016). Teori dan Aplikasi Pemasaran Era Tradisional Sampai Era Modernisasi Global. Bandung: Alfabeta.

Hernandez, B., Jimenez, J., \& Martin, M. J. (2011). Customer Behavior in Electronic Commerce: The Moderating Effect of E-Purchasing Experience. www.sciencedirect.com.

Hidayat, I., Arifin, R., \& Priyono, A. A. (2017). Pengaruh Kepercayaan, Kemudahan, Harga dan Kualitas Informasi Penggunaan E-commerce Terhadap Keputusan Pembelian Secara Online Pada Situs Bukalapak.com. Jurnal Unisma. 
http://www.warungcurhat.com/2017/06/fitur -fitur-yang-memudahkan-di-situsbukalapak/. (2017, Desember).

Indonesia, A. P. (2014). Profil Pengguna Internet Indonesia 2014. Jakarta: Asosiasi Penyelenggara Jasa Internet Indonesia.

Indonesia, A. P. (2016). Statistik Pengguna dan Perilaku Pengguna Internet Indonesia. Jakarta: Asosiasi Penyelenggara Jasa Internet Indonesia.

Khoiroh, Z. (2016). "Pengaruh Kepercayaan, Kemudahan, dan Kualitas Informasi Terhadap Keputusan Pembelian Secara Online (Studi Pada Mahasiswa FEBI IAIN Tulungagung). Skripsi pada Fakultas Ekonomi dan Bisnis Islam Institut Agama Islam Negeri Tulungagung .

Luthfiya, J. (2014). Pengaruh Pemasaran Online Terhadap Keputusan Pembelian Pada Siswa/I SMA Yayasan Pendidikan Harapan 3 Medan. Skripsi pada Fakultas Ekonomi Universitas Sumatera Utara.

Philip Kotler, K. L. (2007). Manajemen Pemasaran, edisi 12 jilid 1. Jakarta: PT Macanan Jaya Cemerlang.

Prabowo, H., Darman, \& Noegraheni, E. (2014). Analisis Kepercayaan Dalam C2C E-commerce Terhadap Keputusan Pembelian dan
Dampaknya Terhadap Repurchase pada Kaskus. Jurnal Binus.

Prayoga, T. P. (2017, August). Diambil kembali dari http://hermantolle.com.

Sari, M. P. (2015). Pengaruh Kepercayaan, Kemudahan dan Kualitas Informasi Terhadap Keputusan Pemblian Secara Online Di Situs Lazada.co.id Pada Mahasiswa/i Fakultas Ekonomi dan Bisnis USU. Skripsi pada Fakultas Ekonomi Universitas Sumatera Utara.

Sen, J. (2008). User Acceptance of Social Shopping Sites: A Research Proposal. aisel.aisnet.org.

Sobirin. (2015). Pengaruh Kualitas Pelayanan Customer Service Terhadap Kepuasaan Nasabah Di PT Bank BRI Unit Aviari Batam (Persero) Tbk. Skripsi pada Politeknik Negeri Batam.

Sugiyono, P. D. (2012). Metode Penelitian Bisnis. Bandung: Alfabeta.

Suliyanto. (2011). Perbedaan Pandangan Skala Likert Sebagai Skala Ordinal atau Skala Interval. UNDIP.

Zulastari, D. I., \& Wardhana, A. (2016). Pengaruh Citra Merek Bukalapak.com terhadap Keputusan Pembelian Konsumen. openlibrary.telkomuniversity.ac.id. 